\title{
Type-specific polysaccharide antigens of group B streptococci*
}

\author{
By REBECCA C. LANCEFIELD AND EARL H. FREIMER \\ The Rockefeller University, New York 21, New York
}

(Received 7 February 1966)

\section{INTRODUCTION}

Since the earliest studies on the serological reactions of group B streptococci, it has been recognized that individual types occur among these micro-organisms and that the antigens differentiating them are probably polysaccharides. These polysaccharides appear to be capsular antigens chemically and serologically distinct from the group-specific carbohydrate contained in the cell-walls. By means of the cell-wall polysaccharide, these streptococci are classified into a single serological group. Antibodies directed against the type-specific polysaccharides of group B streptococci not only give type-specific precipitin reactions, but are also capable of passively protecting mice against infection with mouse-virulent strains of the homologous type.

Investigations of the type-specific antigens of group B streptococci have been almost entirely limited to immunological reactions. Stableforth (1959) was one of the first to study the serological reactions of these organisms in bovine infections. Whether the same serological types occur among strains of human and bovine origin has been the concern of many investigators (Daniels-Bosman, 1959; de Moor, 1959; Jelínková, 1963; Pattison, Matthews \& Howell, 1955; Stableforth, 1932, 1959; Stewart, 1937).

Lancefield (1934) prepared and partially purified group- and type-specific substances of group B strains, using alcohol precipitation as a means of separating the group and type-specific polysaccharides. Griffith (1935) also published an account of his experiments with strain Aronson N (090 in our series), one of the type Ia strains still in use in the present experiments. His work was concerned with characteristics of this strain, such as its virulence, pathogenicity, and ability to induce protective antibodies. Pattison and associates reported studies in cattle and goats of active immunity which was related to serological types; and they studied a serologically active protein antigen in addition to the type-specific polysaccharides (Pattison \& Smith, 1953; Pattison et al. 1955). Recently, interest in possible human pathogenicity of group B strains has been revived and the evidence reviewed by several groups of investigators (Eickhoff et al. 1964; Hood, Janney \& Dameron, 1961).

Further studies on group B streptococci were undertaken in order to define the group- and type-specific antigens more accurately than was previously possible. It became unnecessary to investigate the group-specific carbohydrate in more

* This investigation was supported (in part) by U.S. Public Health Service Grant No. HE 03919. 
detail because a thorough study of this antigen was carried out recently by Curtis \& Krause (1964). They isolated the cell-wall from a strain which had lost its capsule by serial subculture in type-specific serum, and showed that the cell-wall still contained the group-specific polysaccharide. It was similar to other streptococcal cell-wall antigens in that it contained rhamnose. This was the principal determinant sugar, but it was in a different linkage from those rhamnose determinants found in group A-variant and group G streptococci. Wittner \& Hayashi (1965) have reported chemical analyses of fractions isolated from type II strains in preparations extracted with either hot $\mathrm{HCl}$ or Streptomyces albus enzymes. They also found that the group polysaccharide contained a high proportion of rhamnose, and suggested that type-specific activity was found primarily in a galactose-rich fraction.

Our studies of the immunological reactions and chemical components of the type-specific antigen of group B, type II streptococci are presented in the following report.

\section{MATERIALS AND METHODS}

\section{Strains of group $B$ streptococci}

Representatives of the four specific types, Ia, Ib, II, and III, previously studied in this laboratory, were used (Lancefield, 1934). Mouse-virulent strains were employed in order to include the biologically important mouse-protection test in the study. One type II strain, 18RS 21/19, originally isolated from a human throat culture, had become mouse-virulent after nineteen serial passages through mice. A second type II strain, V8, isolated from milk by Dr Theobald Smith in 1915, was not mouse-virulent. Strain $\mathrm{H} 36 \mathrm{~B} / 7$ (type $\mathrm{Ib}$ ), isolated from the blood of a new-born infant, was highly mouse-virulent.

\section{Preparation of antisera}

Sera containing antibodies to the group-specific and type-specific polysaccharides were prepared as previously described (Lancefield, 1938b). In general, groupspecific antisera were obtained from strains devoid of the outer capsular layer of type-specific antigen. Strains rich in type-specific polysaccharide were used to obtain sera with high titres of type-specific antibodies.

\section{Preparation of antigens}

Streptococci grown for $16 \mathrm{hr}$. in $15 \mathrm{l}$. lots of Arnold-sterilized Todd-Hewitt broth were collected and lyophilized. A typical yield from $45 \mathrm{l}$. was $22.0 \mathrm{~g}$. of dry bacteria.

\section{Extraction methods}

(1) Hot $\mathrm{HCl}: 10 \mathrm{~g}$. of lyophilized bacteria were suspended in $100 \mathrm{ml}$. of $\mathrm{HCl}$ ( $\mathrm{pH}$ adjusted to $2 \cdot 0$ ), immersed in a boiling-water bath, and maintained for $10 \mathrm{~min}$. at $96^{\circ} \mathrm{C}$. with continuous stirring. Two additional extractions of the bacterial residue removed most of the serologically active material.

(2) Cold TCA: $12 \mathrm{~g}$. of the same bacteria were suspended in $125 \mathrm{ml}$. of $2.5 \%$ 
trichloracetic acid, bringing the $\mathrm{pH}$ to $2 \cdot 0$. Extraction was carried out just above the freezing point in a Braun cell disintegrator for $5 \mathrm{~min}$. (Bleiweis, Karakawa \& Krause, 1964). Four or five successive extractions removed most of the TCA antigen. After washing the TCA extracted bacterial residue with saline, further extraction at $96^{\circ} \mathrm{C}$. with $\mathrm{HCl}$ at $\mathrm{pH} 2$ yielded $\mathrm{HCl}$ antigen but no further TCA antigen.

\section{Method of purification}

Each $\mathrm{HCl}$ extract was neutralized ( $\mathrm{pH} 7$ ), and the active substances were precipitated at $4^{\circ} \mathrm{C}$. by adding 4 vol. of absolute ethanol. Each TCA extract was precipitated while still acid, and then neutralized. All precipitates were collected by centrifugation, and were dissolved in saline, since electrolytes are essential for alcohol precipitation. At each step in the purification process, insoluble residues were discarded. By testing dilutions of the extracts in capillary precipitin tubes, assays of group- and type-specific activity were obtained. Active $\mathrm{HCl}$ extracts were pooled, as were active TCA extracts; but the pools were kept separate. Each polysaccharide solution was dialysed while being treated first with DNase and RNase, and then with trypsin. Residual proteins, including the enzymes added above, were removed by shaking the solution with chloroform, according to the Sevag technique (Sevag, 1934; Sevag, Lackman \& Smolens, 1938). Residual nucleic acids were removed by adding the anionic exchange resin, Dowex $1-\mathrm{X} 8$ in the $\mathrm{Cl}^{-}$form. The final solutions, which still contained both the group and the type antigens, no longer contained substances giving significant readings at $260 \mathrm{~m} \mu$ or $280 \mathrm{~m} \mu$ as measured by the Beckman spectrophotometer.

\section{Method of separation of the type and group antigens}

The purified $\mathrm{HCl}$ extracts contained large amounts of group-specific antigen, while TCA extracts contained much less. This group-specific polysaccharide could be eliminated from either extract by alcohol fractionation because it did not precipitate until more than 2 vol. of alcohol were added. In general, the type-specific $\mathrm{HCl}$ antigen was precipitated with 1 vol. of ethanol, while the type-specific TCA antigen required $1 \frac{1}{2}$ vol. Each antigen was refractionated until capillary precipitin reactions showed that the removal of group antigen was essentially complete. Finally, each polysaccharide was precipitated with ethanol, and dried with alcohol and ether in vacuo. In one experiment (lot no. 13), $10 \mathrm{~g}$. of bacteria yielded $150 \mathrm{mg}$. of purified $\mathrm{HCl}$ antigen. Twelve $\mathrm{g}$. of bacteria yielded $40 \mathrm{mg}$. of purified TCA antigen, and an additional $55 \mathrm{mg}$. of $\mathrm{HCl}$ antigen on re-extraction of this bacterial residue.

\section{Precipitin analysis}

Quantitative precipitin analyses were done by a spectrophotometric procedure (McCarty \& Lancefield, 1955). 


\section{Immunodiffusion}

Double diffusion was performed by a modification of the Ouchterlony method (Freimer, 1963). Slides for immunoelectrophoresis were prepared by the Sheidegger technique (Sheidegger, 1955).

\section{Analytical methods}

Analyses for rhamnose, glucose, glucosamine, nitrogen and phosphorus were performed as previously described (Freimer, 1963). Galactose was determined by a modified method employing galactose oxidase (galactostat) available from the Worthington Biochemical Corporation, Freehold, New Jersey.

Other techniques are described with the respective experiments.

\section{RESULTS}

Relationship of the mouse protective antibody to the serologically type-specific polysaccharide

Chemical analysis of the type-specific material, obtained by $\mathrm{HCl}$ extraction, showed that three sugars, galactose, glucose, and $N$-acetyl glucosamine, accounted for more than $75 \%$ of its weight. The chemistry of this preparation (referred to as the $\mathrm{HCl}$ antigen), will be considered in detail in a later paper. However, since high concentrations of this antigen did not react with group-specific antisera, and did not contain rhamnose, the principal determinant of the group B antigen, the preparation was essentially free of the group-specific polysaccharide. In contrast, small amounts of this $\mathrm{HCl}$ antigen gave type-specific precipitin reactions with antisera prepared by immunizing rabbits with type II streptococci. High dilutions of the same antisera were shown to protect mice against infection with homologous group B strains, and it became essential to establish the relationship of $\mathrm{HCl}$ antigen to type-specific protection.

Table 1 contains the results of a typical experiment in which the protective effect of an unabsorbed type II antiserum was compared with that of the same serum after it was absorbed with streptococci of homologous or heterologous type. In these passive protection tests, mice were inoculated intraperitoneally with $0.5 \mathrm{ml}$. of a $1 / 200$ dilution of the virulent type II strain, $18 \mathrm{RS} 21 / 19$, containing approximately one million chains of living streptococci. The same syringe contained $0.5 \mathrm{ml}$. of a dilution of serum in saline or of saline alone. Unabsorbed serum and serum absorbed with a suspension of either homologous type II or heterologous type Ib heat-killed streptococci were examined with normal rabbit serum as a control. The results show that the titre of protective antibodies in unabsorbed serum $\mathrm{EE}$ was as high as 9000 , and that this protective property, as well as the precipitins for $\mathrm{HCl}$ antigen, were both eliminated by absorption with streptococci of homologous type. The type-specificity of this phenomenon was demonstrated by the failure of a heterologous strain to remove either the protective or the precipitating antibody. Experiments using other antisera led to similar results, and confirmed the earlier studies with group B streptococci (Lancefield, 1934).

In contrast to these results, when antisera were absorbed with a solution of the 
$\mathrm{HCl}$ polysaccharide, only part of the protective antibody was removed. In these experiments, each serum was absorbed with $\mathrm{HCl}$ antigen at its equivalence point determined by quantitative precipitin analysis with the $\mathrm{HCl}$ polysaccharide. The unabsorbed and absorbed sera were compared for the level of protection they afforded mice inoculated with a virulent type II strain. Although antibody that precipitated with $\mathrm{HCl}$ polysaccharide had been completely absorbed from the serum, protective antibody was only partially removed. This finding suggested that a second antigen-antibody system might also be involved in type-specific protection.

Table 1. Passive protection tests in mice showing the effect of absorbing type II antiserum with homologous and heterologous group $B$ streptococci.

(Challenged with $0.5 \mathrm{ml}$. of a 1/200 dilution of type II streptococci.)

Serum given to mice

\begin{tabular}{|c|c|c|c|c|c|c|c|}
\hline \multirow[b]{3}{*}{ Serum EE (type II)t } & \multicolumn{7}{|c|}{ Dilution* } \\
\hline & 1 & 10 & 100 & 1000 & 6000 & 9000 & 10,000 \\
\hline & & & & & & & \\
\hline Unabsorbed & $\mathrm{s}$ & $\mathrm{s}$ & $\mathrm{s}$ & $\mathrm{s}$ & $\mathrm{S}$ & $\mathrm{s}$ & $\mathrm{D}(1)$ \\
\hline Absorbed with bacteria of & & & & & & & \\
\hline Tyре II (18RS 21/19) & $\mathrm{D}(1)$ & D (1) & D (5) & D (1) & - & - & $\mathrm{D}(1)$ \\
\hline Type II (V 8) & $\mathrm{D}(1)$ & $\mathrm{D}(3)$ & $\mathrm{D}(2)$ & $D(1)$ & $\mathrm{D}(1)$ & $\mathrm{D}(1)$ & $\mathrm{D}(1)$ \\
\hline Type Ib (H 36 B/7) & $\mathrm{s}$ & $\mathrm{S}$ & $\mathrm{s}$ & $\mathrm{s}$ & - & - & $\mathrm{S}$ \\
\hline Normal rabbit serum & $\mathrm{D}(1)$ & $\mathrm{D}(1)$ & $\mathrm{D}(1)$ & D (1) & - & - & $\mathrm{D}(1)$ \\
\hline
\end{tabular}

* Expressed as reciprocal of serum dilution.

† Serum EE was from a rabbit immunized with strain 18RS 21/19.

$\mathrm{D}$ represents death of one mouse with day of death in ( ). $S$ indicates survival for 7 days.

Virulence controls: strain 18RS 21/19 killed control mice in doses which contained from $10^{-1}$ to $10^{-7} \mathrm{ml}$. of the original culture.

\section{Table 2. Precipitin reactions}

$\begin{array}{lcc} & \text { HCl antibody } & \text { TCA antibody } \\ \text { HCl antigen } & ++++ & 0 \\ \text { TCA antigen } & ++++ & ++++\end{array}$

As it was possible that the capsule of the streptococcus contained two distinct antigens, and that $\mathrm{HCl}$ extraction had degraded one of the antigens, other methods of extraction were tried. Extracts made with cold TCA were found to react in precipitin tests with antisera which had been previously absorbed with $\mathrm{HCl}$ antigen. Thus, a second antigen was present in the TCA extract. Furthermore, this 'TCA antigen' was able to absorb both antibodies, the $\mathrm{HCl}$ as well as the TCA, from previously unabsorbed serum, in contrast to the fact that the $\mathrm{HCl}$ antigen only absorbed the $\mathrm{HCl}$ antibody. These relationships, shown in Table 2, indicate that rabbits immunized with type II streptococci produce two distinct type-specific antibodies: the $\mathrm{HCl}$ antibody which reacts with a determinant present in both the $\mathrm{HCl}$ and the TCA antigens, and 'the TCA antibody' reactive with a determinant present solely in TCA antigen. 
Although all of the rabbits immunized with type II strains produced both the $\mathrm{HCl}$ and the TCA antibodies, quantitative precipitin analyses showed that the relative amounts of each antibody varied from serum to serum. The results of an analysis of serum E 4 are shown in Fig. 1. In this experiment, increasing amounts of each antigen were added to $0.1 \mathrm{ml}$. samples of the serum, and the volume of each was adjusted to $1 \cdot 0 \mathrm{ml}$. Equivalence was reached with $60 \mu \mathrm{g}$. of $\mathrm{HCl}$ antigen. With TCA antigen, the equivalence point is not shown in Fig. 1, but more than twice as much antibody globulin precipitated with $60 \mu \mathrm{g}$. of the TCA antigen.

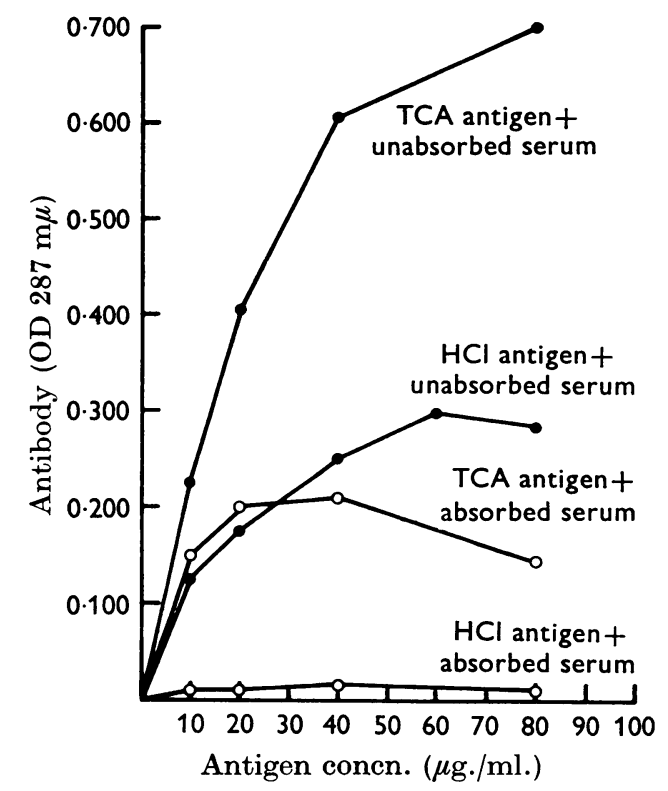

Fig. 1. Quantitative precipitin analysis showing the amount of antibody globulin precipitated with $\mathrm{TCA}$ and with $\mathrm{HCl}$ antigens from unabsorbed serum $\mathrm{E} 4$, and from serum $\mathrm{E} 4$ absorbed at equivalence with $\mathrm{HCl}$ antigen. The antigens were added to $0.1 \mathrm{ml}$. of serum, and the volume adjusted to $1.0 \mathrm{ml}$.

In order to determine how much of this globulin was TCA antibody, a sample of serum $\mathrm{E} 4$ was absorbed near equivalence with $\mathrm{HCl}$ antigen. This absorbed serum was tested with each of the antigens in the manner just described. These results are also plotted in Fig. 1. It is clear that while this absorbed serum no longer precipitated with $\mathrm{HCl}$ antigen, it still reacted with TCA antigen. The amount of antibody precipitated from the absorbed serum with TCA antigen was less than that expected from the results with unabsorbed serum. Recent evidence to be reported later suggests that this was due to inhibition.

The type II specificity of these reactions was tested by preparing $\mathrm{HCl}$ antigens from strains of three heterologous types, and in one instance a TCA antigen (type III from strain D 136C). None of these gave type-specific reactions with type II antisera, although all reacted specifically with their homologous type antisera.

To investigate the relationships suggested by the observations with type II 
polysaccharides, a solution of TCA antigen was brought to $\mathrm{pH} 2$ with $\mathrm{HCl}$, and maintained at $96^{\circ} \mathrm{C}$. for $10 \mathrm{~min}$., the procedure used for extracting $\mathrm{HCl}$ antigen from intact streptococci. This treatment altered the TCA antigen, and resulted in a polysaccharide identical in chemical composition and in immunological reactivity with that of the $\mathrm{HCl}$ antigen. In a parallel experiment, TCA antigen was brought to $\mathrm{pH} 2$ with TCA and heated, but no change was detected. Thus the $\mathrm{HCl}$ antigen appears to be a degraded form of the more complete TCA antigen. TCA antigen contains an additional and more labile component which is lost by heating in the presence of the mineral acid.

Immunodiffusion and immunoelectrophoresis afforded other ways of examining the relationships between these two antigens. When the $\mathrm{HCl}$ and TCA antigens were compared by double diffusion in agar, each formed a precipitin line with unabsorbed type-specific serum, and these precipitin lines joined to form a band of identity. The TCA precipitin line extended beyond the merger, forming a spur which ran toward the well containing the $\mathrm{HCl}$ antigen. This pattern, shown in Pl. $1 a$, supported the concept of two TCA determinants, and demonstrated that they were both part of the same molecule. In addition, the pattern showed that one of these determinants was identical with the $\mathrm{HCl}$ antigen. Two preparations of TCA antigen produced a single band of identity (Pl. 1b). Furthermore, TCA antigen which had been treated with hot $\mathrm{HCl}$ now formed a continuous band of identity with $\mathrm{HCl}$ antigen and a spur with the untreated TCA antigen from which it had been derived (see Pl. $1 c, d$ ). Another pattern which is not illustrated showed that only a single band of precipitate formed between TCA antigen and serum previously absorbed with $\mathrm{HCl}$ antigen. No precipitin line developed between this absorbed serum and $\mathrm{HCl}$ antigen. These patterns confirmed the presence of two antibodies in unabsorbed serum, one reactive with both antigens, and one reactive only with TCA antigen.

The $\mathrm{HCl}$ and the TCA antigens also were compared by immunoelectrophoresis, and a typical pattern is shown in $\mathrm{Pl}$. $1 e$. In this system, using Veronal buffer $(\mathrm{pH} 9 \cdot 3)$, the TCA antigen has migrated toward the anode while the $\mathrm{HCl}$ antigen appears to have moved toward the cathode. It is also apparent that after $\mathrm{HCl}$ treatment of TCA antigen, the treated antigen behaves like $\mathrm{HCl}$ antigen. Other electrophoresis experiments in the same buffer, using Pekivon as a supporting medium, resulted in a more rapid movement of TCA antigen toward the anode, than that of the $\mathrm{HCl}$ antigen which remained essentially at the origin. Thus the TCA antigen clearly has a net negative charge when compared with $\mathrm{HCl}$ antigen.

The isolation of the TCA antigen and its reactivity with two antibodies raised the possibility that both antibodies might play a role in protecting mice against infection with a virulent organism. The observed failure of the $\mathrm{HCl}$ antigen to remove the protective properties of an antiserum completely could thus be explained by the presence of a second protective antibody, the TCA antibody.

In order to examine this hypothesis, passive mouse protection tests were set up, using unabsorbed serum and serum absorbed with each polysaccharide antigen at equivalence, as described in Fig. 1. The results of a typical experiment are recorded in Table 3. When the $50 \%$ end-point of survival was calculated, serum $\mathrm{H}$ was 
found to have a protective titre of 8333 . Serum $\mathrm{H}$ absorbed with $\mathrm{HCl}$ antigen still protected to a $50 \%$ end-point of 2685 , and TCA absorption reduced the titre to 1333. Although it is evident that neither antigen absorbed all of the protective antibody, the TCA antigen did reduce the protective titre by $84 \%$ and the $\mathrm{HCl}$ antigen by $68 \%$. The failure of TCA polysaccharide to absorb all of the protective antibody, although it did remove all of the type-specific precipitins, requires additional consideration. Factors which may play a role are the unusually high titres of protective antibodies in type II sera, coupled with the difficulty of precise achievement of the equivalence point with a soluble antigen. At either side of this point, some antibody remains in solution. When particulate antigens such as bacteria or cell walls are used for absorption, it is obvious that these difficulties do not occur. It is also possible that an additional determinant, not yet discovered, may be responsible for the residual protective antibody.

Table 3. Passive protection tests in mice showing the effect of absorbing type II antiserum with homologous polysaccharides extracted with $\mathrm{HCl}$ or with TCA

(Challenged with $0.5 \mathrm{ml}$. of a 1/200 dilution of type II streptococci.)

\begin{tabular}{|c|c|c|c|c|c|c|c|c|}
\hline \multicolumn{8}{|c|}{ Serum given to mice } & \multirow{3}{*}{$\begin{array}{c}50 \% \text { end-point } \\
\text { of survival } \\
\text { expressed as } \\
\text { serum titre }\end{array}$} \\
\hline & \multicolumn{7}{|c|}{ Dilution* } & \\
\hline & 30 & 100 & $\begin{array}{c}300 \\
\text { Survi }\end{array}$ & $\begin{array}{c}1000 \\
\text { ors/der }\end{array}$ & $\begin{array}{l}3000 \\
\text { hs } \ddagger\end{array}$ & 10,000 & 30,000 & \\
\hline \multicolumn{9}{|l|}{ Serum H $($ Type II $) \dagger$} \\
\hline Unabsorbed & $5 / 0$ & $5 / 0$ & $5 / 0$ & $5 / 0$ & $5 / 0$ & $2 / 3$ & $0 / 5$ & 8333 \\
\hline \multicolumn{9}{|l|}{ Absorbed with } \\
\hline $\mathrm{HCl}$ antigen & $5 / 0$ & $5 / 0$ & $5 / 0$ & $4 / 1$ & $2 / 3$ & $1 / 4$ & $0 / 5$ & 2685 \\
\hline TCA antigen & $5 / 0$ & $5 / 0$ & $5 / 0$ & $3 / 2$ & $0 / 5$ & $0 / 5$ & $0 / 5$ & 1333 \\
\hline Normal rabbit serum & $1 / 4$ & - & - & $1 / 4$ & - & - & - & - \\
\hline
\end{tabular}

In other passive protection tests, unabsorbed type II antisera had $50 \%$ endpoints at serum titres that ranged from 2000 to 10,000 . In one such experiment, serum EE protected at a serum titre of 2000; after absorption with $\mathrm{HCl}$ antigen the level of protection was still 700, while absorption with TCA antigen reduced the level to 100 .

Since the proportion of these two antibodies varied from serum to serum, it seemed desirable to compare their relative protective properties on the basis of equal weights of $\gamma$-globulin. This was accomplished by the formation of specific antigen-antibody precipitates at equivalence, and the subsequent dissociation of a specific $\gamma$-globulin from each complex. As $\mathrm{HCl}$ antigen combined with only one antibody, a specific precipitate containing $\mathrm{HCl}$ antigen and its specific antibody could be prepared from an antiserum containing both antibodies. The preparation of specific globulins was carried out at $4^{\circ} \mathrm{C} . \mathrm{HCl}$ antigen, dissolved in saline, was 
mixed with serum $\mathrm{H}$, and after $16 \mathrm{hr}$. the specific precipitate was collected by centrifugation. The serum supernatant then contained only the TCA antibody which was precipitated by adding TCA antigen in small increments. When no further precipitate developed, this TCA precipitate was collected. Each antigen-antibody complex was washed with cold $0.05 \mathrm{~m}$ phosphate-buffered saline $(\mathrm{pH} 7 \cdot 3)$ until free of soluble protein, and then dissolved in $0.1 \mathrm{~m}$ glycine buffer $(\mathrm{pH} 3)$. After removing insoluble material by centrifugation, the dissociated $\gamma$-globulin was precipitated by 0.33 saturation of the solution with ammonium sulphate. Each precipitated globulin was dissolved in saline, and concentrated by vacuum dialysis against phosphate-buffered saline. In addition to the $\mathrm{HCl}(3 \mathrm{E})$ and TCA (3K) specific globulins, a globulin solution containing both antibodies $(4 \mathrm{E})$ was prepared from a specific precipitate of TCA antigen and serum $\mathrm{H}$. In order to begin with equal weights of globulin, solutions of the three specific antibody globulins were diluted with phosphate-buffered saline so that each contained the same protein concentration, O.D. of $0 \cdot 100$ (at $287 \mathrm{~m} \mu$ ).

\section{Table 4. Passive protection tests in mice showing the protective effect of equal weights of $\mathrm{HCl}$ and TCA antibody globulins}

(Challenged with $0.5 \mathrm{ml}$. of a $1 / 200$ dilution of type II streptococci.)

$\gamma$-Globulin solutions given to mice

\begin{tabular}{|c|c|c|c|c|c|c|c|c|c|}
\hline \multirow[b]{3}{*}{ Fraction* } & \multirow[b]{3}{*}{$\begin{array}{l}\text { O.D. un- } \\
\text { diluted }\end{array}$} & \multicolumn{7}{|c|}{ Dilution $†$} & \multirow{3}{*}{$\begin{array}{c}50 \% \text { end-point } \\
\text { of survival } \\
\text { expressed as } \\
\text { O.D. }\end{array}$} \\
\hline & & 1 & 2 & 4 & 10 & & 40 & 100 & \\
\hline & & \multicolumn{7}{|c|}{ Survivors/deaths $\ddagger$} & \\
\hline $\begin{array}{l}\text { Specific } \mathrm{HCl} \text { antibody } \\
\text { globulin }(3 \mathrm{E})\end{array}$ & $0 \cdot 100$ & $5 / 0$ & $5 / 0$ & $5 / 0$ & $5 / 0$ & $1 / 4$ & $0 / 5$ & $1 / 4$ & 0.006 \\
\hline Specific TCA antibody & $0 \cdot 100$ & $5 / 0$ & $5 / 0$ & $5 / 0$ & $2 / 3$ & $0 / 5$ & $0 / 5$ & $0 / 5$ & 0.012 \\
\hline $\begin{array}{l}\text { Specific } \mathrm{HCl} \text { and TCA } \\
\text { antibody globulins }(4 \mathrm{E})\end{array}$ & $0 \cdot 100$ & $5 / 0$ & $5 / 0$ & $5 / 0$ & $5 / 0$ & $3 / 2$ & $3 / 2$ & $0 / 5$ & $0 \cdot 003$ \\
\hline $\begin{array}{l}\text { Total immune } \\
\text { globulin }(2 \mathrm{~B})\end{array}$ & $0 \cdot 400$ & - & $10 / 0$ & $10 / 0$ & $10 / 0$ & $9 / 1$ & $3 / 7$ & $3 / 7$ & $0 \cdot 011$ \\
\hline $\begin{array}{l}\text { Total normal } \\
\text { globulin (1 B) }\end{array}$ & $\S$ & $0 / 5$ & - & - & & - & - & - & - \\
\hline $\begin{array}{l}\text { * The antibody glo } \\
\dagger \text { Expressed as reci } \\
\ddagger \text { No. of mice survi } \\
\S \text { The volume of no } \\
\text { Techniques: See }\end{array}$ & $\begin{array}{l}\text { bulins we } \\
\text { procal of } \\
\text { ving/no. } \\
\text { ormal glo } \\
\text { Table } 1 .\end{array}$ & $\begin{array}{l}\text { fror } \\
\text { obul } \\
\text { ing. } \\
\text { lin }\end{array}$ & $\begin{array}{l}\text { dilut } \\
\text { adjum }\end{array}$ & $\begin{array}{l}{[\text { (see }} \\
\text { ed to }\end{array}$ & able : & & & T & \\
\hline
\end{tabular}

Finally, two additional solutions were prepared with ammonium sulphate: a positive control which contained the total gamma globulin fraction (2B) of serum $\mathrm{H}$; and a negative control containing the same fraction (1B) of a normal rabbit serum. Each of these globulin solutions was reconstituted to the original serum volume with phosphate buffer. The protein concentration of the immune globulin solution $(2 \mathrm{~B})$ had an o.D. reading of 0.400 (at $287 \mathrm{~m} \mu$ ). 
Serial dilutions of the immune globulins were prepared at $1 / 3$ log intervals, and each dilution was given to five mice in combination with a virulent type II culture. The undiluted normal globulin was given to five mice. The results of this experiment are shown in Table 4, in which the $50 \%$ end point of survival is expressed as the o.D. The variability was within the experimental limits of the biological nature of the test system. Relatively small amounts of each specific globulin protected mice from infection with homologous strains, and the results indicated that the $\mathrm{HCl}$ and the TCA globulins are equally protective. These findings suggest that when either $\mathrm{HCl}$ or TCA antibody binds to its specific antigenic site it so alters the bacterial surface that phagocytosis can occur and mice challenged with these streptococci are protected from infection.

These experiments led to renewed studies of the chemical basis for serological specificity of these two type-specific polysaccharides. Although a detailed report of these findings will appear in a subsequent publication, it may be briefly stated that the type II $\mathrm{HCl}$ antigen contains $26 \%$ of glucose, $14 \%$ of glucosamine, and $35 \%$ of galactose. The galactose, in a $\beta$ linkage, is the principal determinant of the serological specificity of the $\mathrm{HCl}$ antigen. In addition to the same proportion of these three sugars, the TCA antigen also contains other components which represent $30 \%$ of its weight. These contribute the negative charge to this molecule as well as the additional serological specificity.

\section{DISCUSSION}

The unusual finding of two distinct protective type-specific antibodies directed against different determinants in the capsule of the same group B streptococcal strain led to an investigation of the immunological and chemical relationships of the antigens involved. Both antibodies are specific for type II, and both protect mice against infection with a mouse-virulent strain of the same serological type. Moreover, equal weights of the two specific globulins are equally protective. Three sugars, galactose, glucose and glucosamine, comprise more than $75 \%$ of the $\mathrm{HCl}$ extracted antigen. The same three sugars are present in the TCA extracted antigen as well as an additional serologically active component not yet identified chemically. This component is more labile than the $\mathrm{HCl}$ antigen, and is split off by heating with dilute $\mathrm{HCl}$. By this hydrolysis the TCA antigen is converted to an antigen which appears to be immunologically and chemically identical with the $\mathrm{HCl}$ extracted antigen.

These results are reminiscent of the studies of Avery \& Goebel in which they found that the specific polysaccharide of the type I Pneumococcus was either acetylated or deacetylated depending upon the methods of extraction and purification (Avery \& Goebel, 1933). The acetyl radical of this polysaccharide was exceedingly labile when exposed to strong alkali. They reported two serologically distinct reactions: one antibody was directed against the deacetylated polysaccharide; the specificity of the other antibody was determined by the presence of an acetyl radical. As the acetyl-polysaccharide absorbed all of the protective antibody, and the deacetylated polysaccharide only absorbed a small part of the 
protective antibody, these authors reasoned that the antibody directed against the acetyl-polysaccharide was the major one involved in type I protection. Methods were not available at the time of these studies to isolate specific antibody globulins in order to compare their protective value. Consequently a close parallel between their results and those which we have obtained with the two group B, type II protective systems can only be suggested as being possible. The tentative nature of this comparison is also dependent upon the identification of the chemical nature of the TCA determinant in the group B, type II antigen.

Several other antigen-antibody systems with a similar dual specificity but without protective properties, are known. They include: (1) the polyglycerophosphate antigen described by McCarty which exists either with or without an ester-linked D-alanine, each form being serologically distinctive (McCarty, 1964); (2) the group A and A-variant cell-wall polysaccharides in which the terminal serologically active radical in group A strains is $N$-acetyl-glucosamine, with the underlying serologically distinct rhamnose-rhamnose linkages characteristic of the A-variant streptococcus (McCarty, 1956); and (3) the intermediate cell-wall polysaccharides found in groups $\mathrm{C}$ and $\mathrm{G}$ by Krause (1963).

What may represent another of these relationships has long been known in group B. Strains placed in types now designated as Ia and Ib were originally all classified as type $I$ on the basis of precipitin reactions and reciprocal protection (Lancefield, 1938a). Discrepancies began to appear as numerous antisera were tested, and reciprocal absorption experiments using whole streptococci as absorbing agents distinguished cross-reactive antibodies from those specific for either Ia or I b strains. As has been shown in preliminary experiments not yet reported, these differences are reflected in the serological reactions of the purified types $\mathrm{Ia}$ and $\mathrm{Ib}$ polysaccharides. The complex relationships of types $I a$ and $I b$, have not yet been clarified.

\section{SUMMARY}

Rabbits immunized with whole streptococci of group B, type II, produce two immunologically distinct type-specific antibodies which are essentially equal by weight in protecting mice against infection with homologous type strains.

The capsular antigen with which these antibodies react is a polysaccharide containing galactose, glucose, glucosamine, and a labile component which has not been chemically identified. Extraction of the bacteria with TCA yields this 'complete' antigen, whereas extraction with $\mathrm{HCl}$ yields a partial antigen without the labile component. This degraded antigen can also be derived from the TCA antigen by treating the latter with hot $\mathrm{HCl}$, and is indistinguishable from that extracted directly from the bacteria with $\mathrm{HCl}$.

One of the antibodies produced, the TCA antibody, is directed against the labile component of the polysaccharide. The other, the $\mathrm{HCl}$ antibody, is directed against a $\beta$-D-galactoside determinant; and the precipitin reaction with this antibody is not masked in the "complete' TCA antigen by the presence of thelabile component.

The group-specific polysaccharide, which is located in the cell-wall, is also extracted with either TCA or $\mathrm{HCl}$ but can be eliminated from the preparations by 
fractional precipitation with ethanol. Although it is known that the type-specific polysaccharide is located in the streptococcal capsule, it is not at present clear in what form this substance occurs in the living streptococcal cell. It may be present partially as the degraded $\mathrm{HCl}$ form, or possibly wholly as the intact TCA form. Further immunological and chemical studies of these type-specific polysaccharides are in progress, and will be presented in another communication.

It is a pleasure to thank Mrs Christa M. Levine and Mr W. N. Everly for their skilled technical assistance.

\section{REFERENCES}

Avery, O. T. \& Goebel, W. F. (1933). Chemoimmunological studies on the soluble specific substance of pneumococcus. I. The isolation and properties of the acetyl polysaccharide of pneumococcus type I. J. exp. Med. 58, 731.

Bleiweis, A. S., Karakawa, W. W. \& Krause, R. M. (1964). Improved technique for the preparation of streptococcal cell walls. J. Bact. 88, 1198.

Curtis, S. N. \& Krause, R. M. (1964). Antigenic relationships between groups B and G streptococci. J. exp. Med. 120, 629.

Daniels-Bosman, M. S. M. (1959). Bij de mens gekweekte streptococci van groep B. Amsterdam: Rototype/Broos.

DE Moor, C. E. (1959). II. (a) De humane en de boviene Streptococcus agalactiae. (b) Streptococcus uberis. Drieenzestigste Wetenschappelijke Vergadering, gehouden op maandag.

Eickhoff, T. C., Klein, J. O., Daly, A. K., Ingall, D. \& Finland, M. (1964). Neonatal sepsis and other infections due to group B beta-hemolytic streptococci. New Engl. J. Med. $271,1221$.

Freimer, E. H. (1963). Studies of $\mathrm{L}$ forms and protoplasts of group A streptococci. II. Chemical and immunological properties of the cell membrane. J. exp. Med. 117, 377.

GRIFFITH, F. (1935). The Aronson streptococcus. J. Hyg., Camb., 35, 23.

Hood, M., Janney, A. \& Dameron, G. (1961). Beta hemolytic streptococcus group B associated with problems of the perinatal period. Am. J. Obstet. Gynec. 82, 809.

JeLf́nková, J. (1963). Sérologická typizace hemolytických streptokokủ skupiny B. Čslká. Epidem., Mikrobiol. Immunol. 12, 74.

KRAUSE, R. M. (1963). Symposium on relationship of structure of microorganisms to their immunological properties. IV. Antigenic and biochemical composition of hemolytic streptococcal cell walls. Bact. Rev. 27, 369.

LANCEFIELD, R. C. (1934). A serological differentiation of specific types of bovine hemolytic streptococci (group B). J. exp. Med. 59, 441.

LANCEFIELd, R. C. (1938a). Two serological types of group B hemolytic streptococci with related, but not identical, type-specific substances. J. exp. Med. 67, 25.

LANCEFIELD, R. C. (1938b). A micro precipitin-technic for classifying hemolytic streptococci, and improved methods for producing antisera. Proc. Soc. exp. Biol. Med. 38, 473.

MCCARTY, M. (1956). Variation in the group-specific carbohydrate of group A streptococci. II. Studies on the chemical basis for serological specificity of the carbohydrates. $J$. exp. Med. 104, 629.

McCARTy, M. (1964). The role of D-alanine in the serological specificity of group A streptococcal glycerol teichoic acid. Proc. natn. Acad. Sci., U.S.A. 52, 259.

MCCARTy, M. \& LANCEFIELD, R. C. (1955). Variation in the group-specific carbohydrate of group A streptococci. I. Immunochemical studies on the carbohydrates of variant strains. J. exp. Med. $102,11$.

Pattison, I. H. \& Smith, I. M. (1953). The histology of experimental Streptococcus dysgalactiae mastitis in goats. J. Path. Bact. 66, 247.

Pattison, I. H., Matthews, P. R. J. \& Howell, D. G. (1955). The type classification of group B streptococci with special reference to bovine strains apparently lacking in type polysaccharide. J. Path. Bact. 69, 51.

Scheidegger, J. J. (1955). Une micro-méthode de l'immuno-electrophorèse. Int. Archs Allergy appl. Immun. 7, 103. 

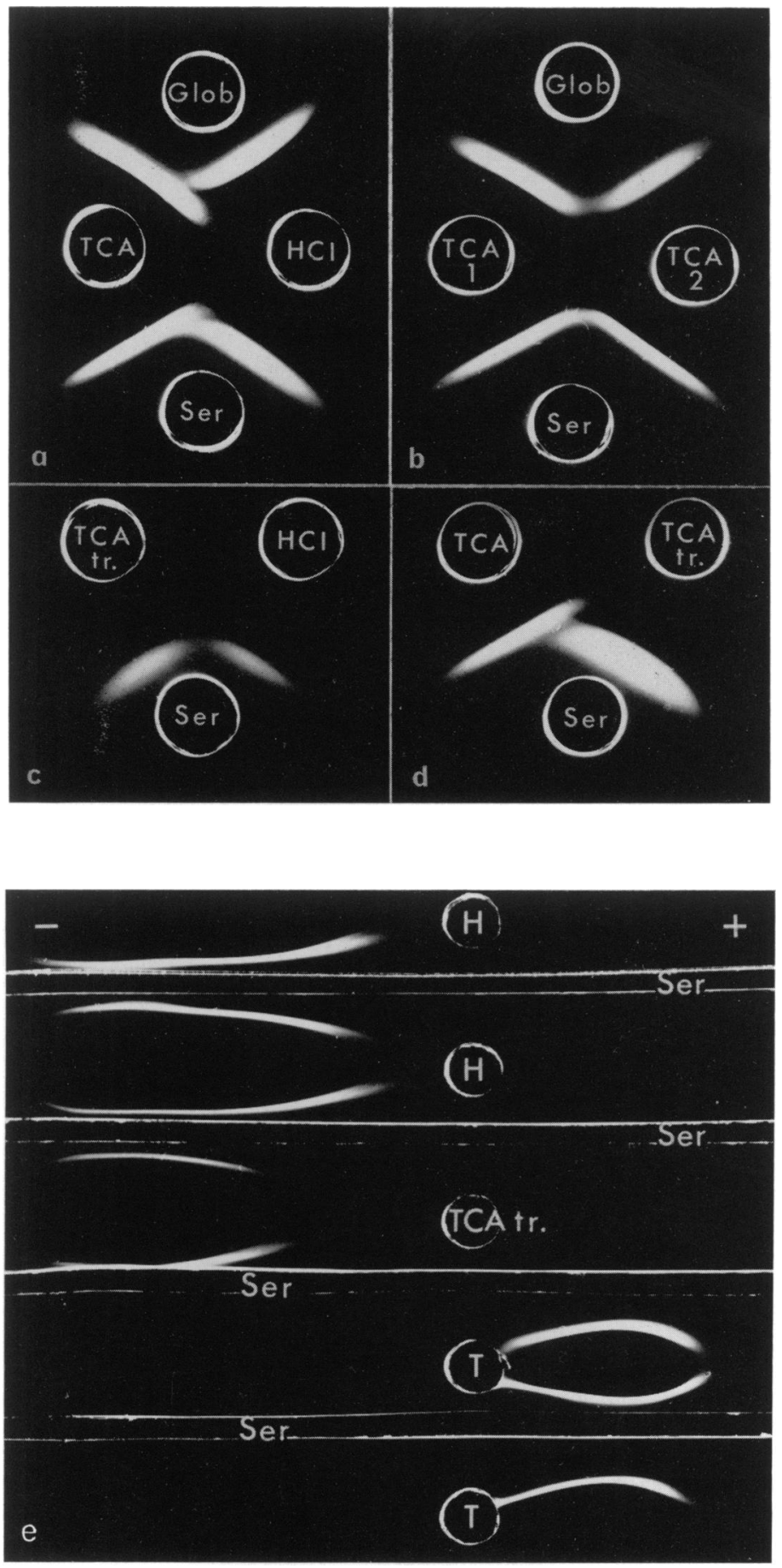
Sevag, M. G. (1934). Eine neue physikalische Enteiweiszungsmethode zur Darstellung biologisch wirksamer Substanzen. Biochem. Z. 273, 419.

Sevag, M. G., Lackman, D. B. \& Smolens, J. (1938). Isolation of components of streptococcal nucleoproteins in serologically active form. $J$. biol. Chem. 124, 425.

Stableforth, A. W. (1932). Studies on bovine mastitis. VII. The serological characters of mastitis streptococci. J. comp. Path. Ther. 45, 185.

Stableforth, A. W. (1959). Streptococcal Diseases. Diseases due to bacteria, vol. II, p. 589. New York: Academic Press, Inc.

StewART, D. F. (1937). Group classification and serological typing of streptococci associated with bovine mastitis in Australia. J. Path. Bact. 45, 279.

Wittner, M. K. \& Hayashi, J. A. (1965). Studies of streptococcal cell walls. VII. Carbohydrate composition of group B cell walls. J. Bact. 89, 398.

\section{EXPLANATION OF PLATE}

$(a)-(d)$ Microimmunodiffusion slides demonstrating the relationships between TCA and $\mathrm{HCl}$ antigens. TCA antigens are in wells marked TCA 1 and TCA 2, while $\mathrm{HCl}$ antigen is in wells marked HCl.

(a) The precipitin lines of the TCA and the $\mathrm{HCl}$ antigens have joined to form a band of identity. The TCA line shows a spur which indicates the presence of a second determinant as part of this molecule. No essential difference is noted between the unabsorbed type II serum EE (Ser.) and the concentrated globulin fraction (Glob) obtained from another unabsorbed type II antiserum $\mathbf{H}$.

(b) The identity of two preparations of TCA antigens.

(c) The identity of TCA antigen treated with hot $\mathrm{HCl}$ (TCA tr.) and $\mathrm{HCl}$ antigen.

$(d)$ The formation of a spur between (TCA tr.) and the original TCA antigen.

(e) Immunoelectrophoretic comparison of $\mathrm{HCl}$ antigen $(\mathrm{H})$, TCA antigen $(\mathrm{T})$, and TCA antigen treated with hot HCl (TCA tr.). The patterns have been developed with unabsorbed type II antiserum EE (Ser) 